Short Communication

\title{
NGF-induced neurite outgrowth in PC12 cells is independent of calcium entry through L-type calcium channels
}

\author{
Lucia Lichvárová, Katarína Jašková and Lubica Lacinová \\ Institute of Molecular Physiology and Genetics, VVCE Biomembranes, Slovak Academy of Sciences, Bratislava, Slovak \\ Republic
}

\begin{abstract}
Neuronal growth factor (NGF) induces neurodifferentiation of PC12 cells into cholinergic neurons-like cells. It was shown that intracellular $\mathrm{Ca}^{2+}$ ions participate in regulation of the differentiation of PC12 cells. We tested whether L-type calcium channels contribute to $\mathrm{Ca}^{2+}$ entry which supports neurite outgrowth accompanying NGF-activated differentiation process. Development of morphological changes did correlate with increase of functional expression of L-type calcium channels. However, inhibition of L-type calcium channels by $1 \mu \mathrm{M}$ of isradipine did not affect significantly an NGF-activated neurite outgrowth.
\end{abstract}

Key words: PC12 cells - L-type calcium channels - Dihydropyridines - Neurite outgrowth

PC12 cell line was established almost 50 years ago by Greene and Tischler (Greene and Tischler 1976) from a rat adrenal pheochromocytoma. Nerve growth factor (NGF) initiates rapid phenotypic change of these cells manifested by the outgrowth of neurites, induction of a number of genes and development of electrical excitability (Greene and Tischler 1976; Pollock et al. 1990). PC12 cells are commonly used as a model system for study of signaling pathways controlling neurodifferentiation.

An initial step in signaling cascade which mediates NGF-dependent neurodifferentiation is binding of NGF to tyrosin kinase receptor type 1 or TrkA (Vaudry et al. 2002). This pathway encompasses number of protein kinases including protein kinase A (PKA), protein kinase $\mathrm{C}(\mathrm{PKC})$ and inositol $(1,4,5)$ trisphosphate 3-kinase (IP3K) which eventually regulate activity of extracellular signalregulated kinase (ERK) phosphorylation (Vaudry et al. 2002). Activation of both PKA and PKC supports NGFdriven neurite outgrowth (Kolkova et al. 2000; Hansen et al. 2003). In contrast, IP3K attenuates ERK phosphorylation and so opposes NGF driven neurite outgrowth (Eva et al. 2012).

Correspondence to: Lubica Lacinová, Institute of Molecular Physiology and Genetics, VVCE Biomembranes, Slovak Academy of Sciences, Bratislava, Slovak Republic

E-mail: lubica.lacinova@savba.sk lucia.lichvarova@savba.sk
Signaling pathways which mediate NGF-driven neurodifferentiation are modulated by free intracellular $\mathrm{Ca}^{2+}$ ions. Increase in cytoplasmic calcium concentration via activation of intracellular sigma-1 and IP3 receptors potentiated NGF-activated neurodifferentiation of PC12 cells (Ishima and Hashimoto 2012). Calcium ions from extracellular environment may enter PC12 cells via TRP (transient receptor potential) channels (Puntambekar et al. 2005; Meng et al. 2008), voltage-dependent L- and N-type calcium channels (Usowicz et al. 1990; Cavalie et al. 1994; Liu et al. 1996; Colston et al. 1998) or $\mathrm{Na}^{+}-\mathrm{Ca}^{2+}$-exchanger (Meng et al. 2008; Oda et al. 2011; Sirabella et al. 2012). Influx of $\mathrm{Ca}^{2+}$ through the TRPC1 but not through the TRPC5 channels potentiated NGF-driven neurite outgrowth (Heo et al. 2012; Kumar et al. 2012). Activity of $\mathrm{Na}^{+}-\mathrm{Ca}^{2+}$-exchanger facilitated NGF-driven neurite outgrowth (Oda et al. 2011). Increased extracellular calcium concentration facilitated also staurosporine-induced neuronal differentiation of PC12 cells (Zhaleh et al. 2011), however, entry pathway for $\mathrm{Ca}^{2+}$ in these experiments was not identified by the authors. In current work we analyzed the role of calcium entry via Ltype calcium channels (LTCC) in NGF-dependent neurite outgrowth in PC12 cells.

PC12 cells were purchased from DSMZ (Deutsche Sammlung von Mikroorganismen und Zellkulturen $\mathrm{GmbH}$, Braunschweig, Germany) and grown in DMEM with Lglutamin, 20\% fetal bovine serum and $100 \mathrm{U} / \mathrm{ml}$ penicillinstreptomycin in an atmosphere of $5 \% \mathrm{CO}_{2}$ and $95 \%$ air at 
$37^{\circ} \mathrm{C}$. After plating out into $35 \mathrm{~mm}$ Petri dishes (day 0) cell differentiation was initiated by supplementing the culture medium with $50 \mathrm{ng} / \mathrm{ml}$ of NGF. Transcription and expression of LTCCs and neurite outgrowth was evaluated on the day 2, 5, 7 and 9 of the NGF treatment.
For evaluation of neurite outgrowth PC12 cells were seeded into $35 \mathrm{~mm}$ Petri dishes with scored coordinate system approximately 10 days after thawing and divided into three groups (50 ng/ml NGF; 50 ng/ml NGF + 20 nl/ml DMSO; 50 ng/ml $\mathrm{NGF}+1 \mu \mathrm{M}$ isradipine). On the day 2, 5, 7 and 9 culture
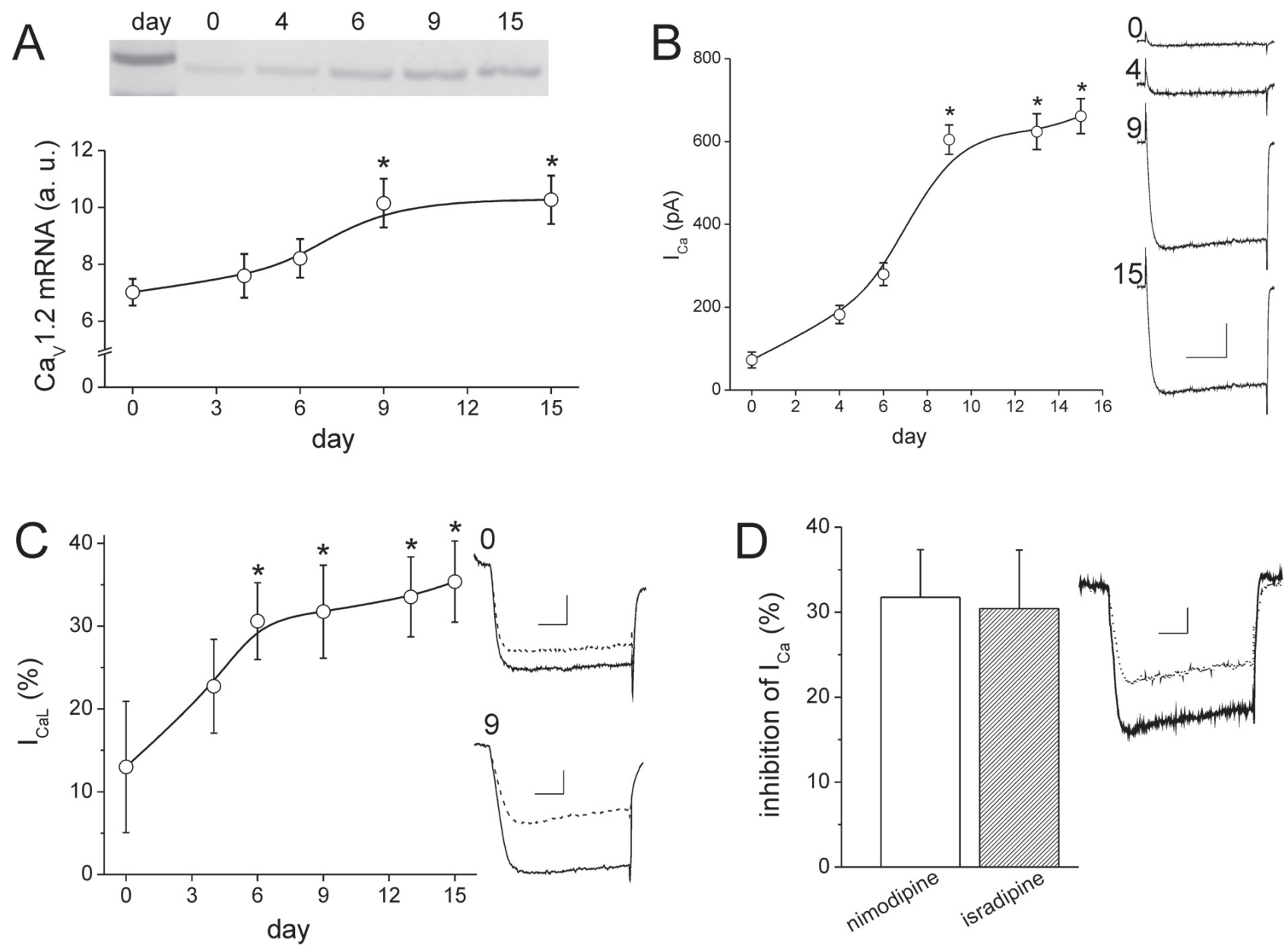

Figure 1. A. Concentration of mRNA for the CACNA1C gene encoding the $\alpha_{1}$ subunit of the Cav 1.2 calcium channel was evaluated relative to the concentration of mRNA for housekeeping GAPDH gene. Day 0 represents PC12 cells not treated with NGF. Axis x represents time of cell culture in the presence of $50 \mathrm{ng} / \mathrm{ml} \mathrm{NGF}$. Each point represents a mean \pm SEM from 5 independent experiments. * significantly different from the day $0, p<0.05$. An example of a gel with bands corresponding to an amplified fragment of CACNA1C mRNA is shown on the top. B. Total calcium current amplitude measured from cells not treated with NGF (day $0 ; n=23$ ) and cells cultured for 4 ( $n=4$ ), $6(n=9), 9(n=11), 13(n=11)$ and $15(n=9)$ days in presence of $50 \mathrm{ng} / \mathrm{ml} \mathrm{NGF}$. Each point represents a mean \pm SEM. ${ }^{*}$ significantly different from the day $0, p<0.05$. Examples of current traces recorded at experimental days as marked are shown on the right. Common scale bars represent $50 \mathrm{~ms}$ and $500 \mathrm{pA}$. C. Percentage of L-type calcium current in the total calcium current was evaluated as a percentage of total calcium current blocked by $10 \mu \mathrm{M}$ nimodipine. Each point represents a mean \pm SEM. Number of individual experiments at each day was the same as in the panel B. ${ }^{*}$ significantly different from the day $0, p<0.05$. Examples of current traces recorded at experimental days as marked are shown on the right. Solid black lines correspond to the current trace recorded under the control conditions. Dashed lines show the current trace amplitude measured in equilibrium with $10 \mu \mathrm{M}$ nimodipine. Scale bars represent $10 \mathrm{~ms}$ and $100 \mathrm{pA}$. D. Comparison of the inhibition of $\mathrm{I}_{\mathrm{Ca}}$ by $10 \mu \mathrm{M}$ nimodipine and $1 \mu \mathrm{M}$ isradipine. PC12 cells were conditioned for 9 days with NGF. Columns represent mean \pm SEM inhibition of current amplitude by each respective drug. 11 and 7 cells were tested with nimodipine and isradipine, respectively. Data for nimodipine are the same as in the panel $\mathrm{C}$ day 9. Example of current traces measured under the control conditions (solid line) and in equilibrium with $1 \mu \mathrm{M}$ isradipine (dashed line) is given on the right. Scale bars represent $10 \mathrm{~ms}$ and $100 \mathrm{pA}$. 
dishes were photographed on Olympus X71 microscope for an evaluation of neurite outgrowth. After photographing 50\% of culture medium with additives as listed above was exchanged. Cells exposed to isradipine were preserved from light. Whole experiment was repeated three times. Each experiment consisted of 12 replicates (3 Petri dishes/4 fields each). Figure 2 demonstrates a representative field cultured at condition as marked photographed at days 2, 5, 7, and 12 .

Expression of the CACNA1C gene encoding the $\alpha_{1}$ subunit of the $\mathrm{Ca}_{\mathrm{V}} 1.2$ channel was evaluated by RT-PCR analysis from total cell lysates of PC12 cells harvested on indicated days. Total RNA was isolated by TRI Reagent (Sigma) and homogenized for 5 minutes at a room temperature. Total RNA was extracted by chloroform/isopropanol precipitation (SERVA). After centrifugation RNA pellet was washed with $70 \%$ ethanol and precipitated in $96 \%$ ethanol (SERVA) at $-20^{\circ} \mathrm{C}$ overnight. Samples were stored for longer time at $-70^{\circ} \mathrm{C}$. The purity and integrity of isolated RNAs was checked spectrophotometricaly on nanophotometer (IMPLEN). Reverse transcription was performed using $1.5 \mu \mathrm{g}$ of total RNAs and Ready-To-Go You-Prime First-Strand Beads (GE Healthcare) with Random Hexamer Primer (Fermentas). For subsequent PCR amplification following primers were used: CACNA1C forward primer 5'-GAC CGG GGA GGA CTG GAA TT-3' and reverse primer 5'-GGC CAG CTT CTT CCT CTG CTT-3'. GAPDH primers: forward 5'-AGA TCC ACA ACG GAT ACA TT-3' and reverse: 5' -TCC CTC AAG ATT GTC AGC AA-3' were used to amplify a housekeeper gene for semi-quantitative evaluation of PCR products. Each PCR program started with initial denaturation at $94^{\circ} \mathrm{C}$ for $5 \mathrm{~min}$, followed by 33 (for $\mathrm{Ca}_{V} 1.2$ ) or 20 (for GAPDH) cycles of denaturation at $94^{\circ} \mathrm{C}$ for $1 \mathrm{~min}$, annealing at $61^{\circ} \mathrm{C}$ for $1 \mathrm{~min}\left(60^{\circ} \mathrm{C}\right.$ for GAPDH) and polymerization at $72^{\circ} \mathrm{C}$ for $1 \mathrm{~min}$. PCRs were terminated by a final polymerization at $72^{\circ} \mathrm{C}$ for $5 \mathrm{~min}$. All PCR products were analyzed on $2 \%$ agarose gels (Jurkovicova et al. 2007).

Expression of functional calcium channel proteins was assessed by measuring of inward calcium currents. Whole-cell configuration of the patch-clamp technique with the HEKA10 patch-clamp amplifier (HEKA Electronic, Lambrecht, Germany) was used. The extracellular solution contained (in $\mathrm{mM}$ ): $\mathrm{NaCl} \mathrm{130,} \mathrm{KCl} 4, \mathrm{BaCl}_{2} 20, \mathrm{MgCl}_{2}$ 1, HEPES 10, glucose 10, pH 7.4 (with $\mathrm{NaOH}$ ). The intracellular solution contained (in mM): CsCl 100, EGTA 14, $\mathrm{NaCl} \mathrm{10,} \mathrm{TEA-Cl}$ 20, Mg-ATP 5, Na-GTP 0.3, HEPES 20, pH 7.4 (with CsOH). The osmolarity of the internal solution was approximately $300 \mathrm{mOsm}$; the osmolarity of the external solution was adjusted by adding glucose to a final value 2-3 mOsm lower than the osmolarity of the internal solution. Extracellular solutions were exchanged by a gravity-driven flow system with manually controlled valves. Patch pipettes were manu- day 2

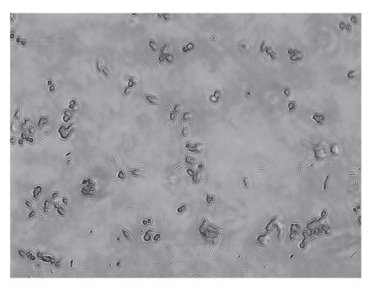

control
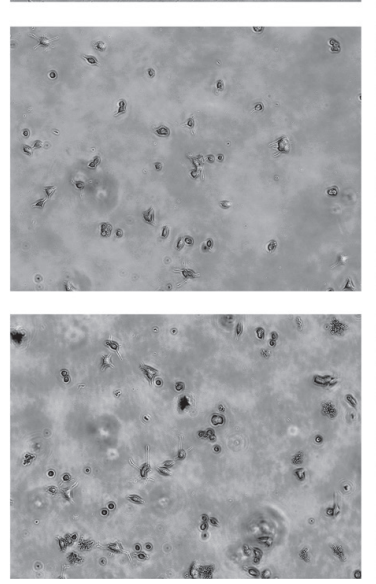

day 5
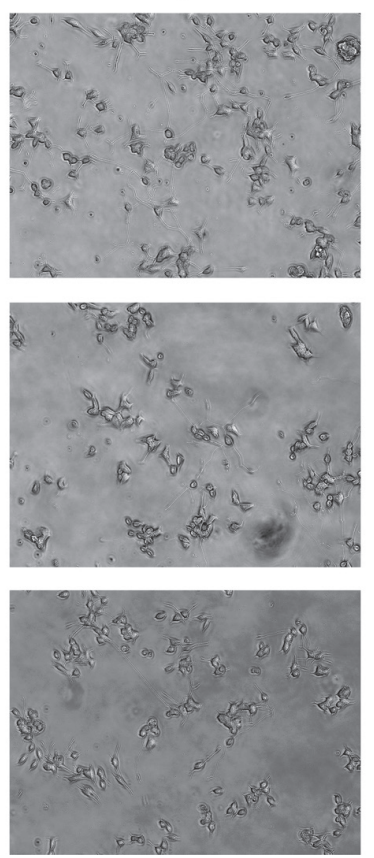

day 7
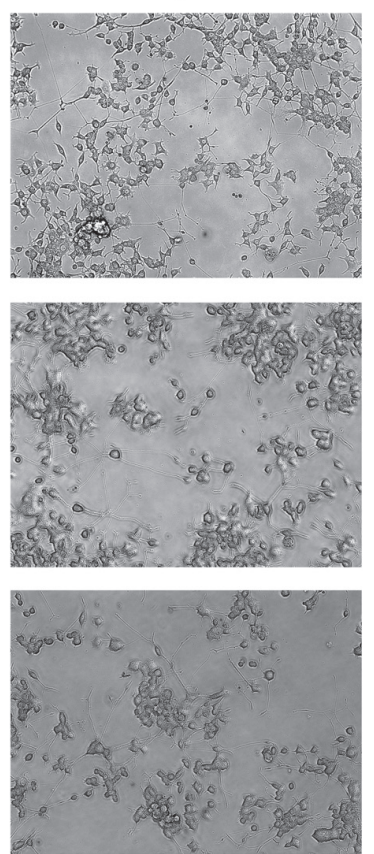

day 9
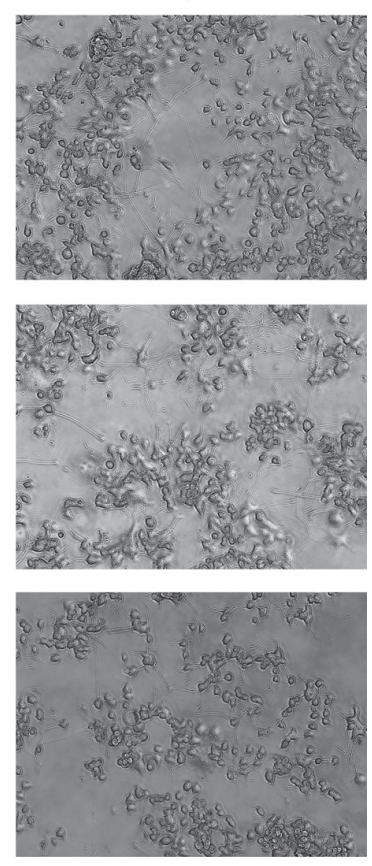

Figure 2. Example of photographs taken from cell culture dishes maintained for 2, 5, 7 and 9 days as marked in the presence of $50 \mathrm{ng} / \mathrm{ml}$ NGF (upper row), NGF and $20 \mathrm{nl} / \mathrm{ml}$ DMSO (middle row) and NGF and $1 \mu \mathrm{M}$ isradipine (lower row). All photograps in each row were taken from the same cell culture dish. Photographs are representatives for 3 independent experiments. Actual size of photographed field was $920 \mu \mathrm{m} \times 680 \mu \mathrm{m}$. 
factured from borosilicate glass (Sutter Instrument, Novato, CA) with input resistance ranging from 1.6 to $2.0 \mathrm{M} \Omega$. The cell capacitance ranged between 20 and 80 pF. Capacity transient and series resistance were compensated up to $70 \%$. Residual linear leak current was subtracted by built-in procedure of the EPC 10 amplifier.

Data are presented as mean \pm SEM. Values measured at individual days were compared by one-way ANOVA with Tukey post-test and $p<0.05$ was considered significant.

Concentration of the mRNA for CACNA1C gene evaluated by the RT-PCR analysis followed sigmoidal time course reaching a plateau after the day 8 (Figure 1A). Same time
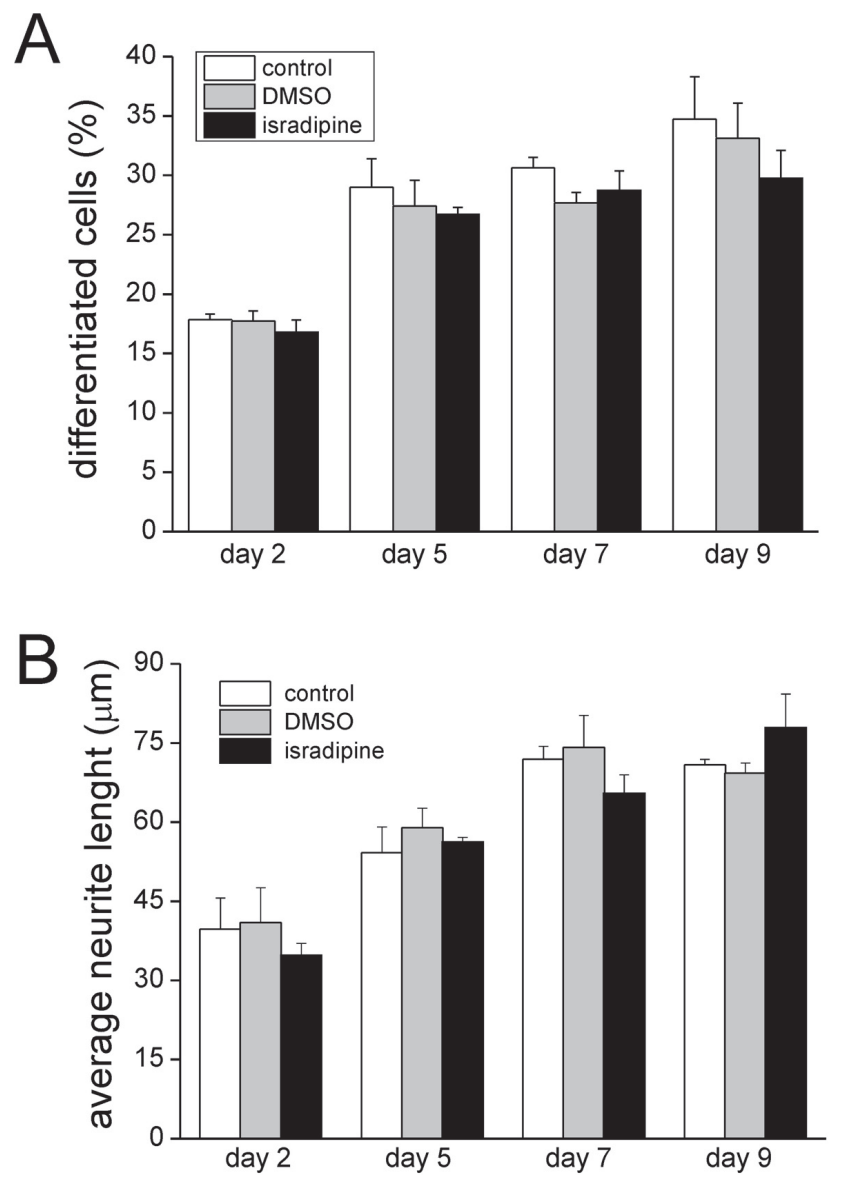

Figure 3. A. Percentage of differentiated cells after 2, 5, 7 and 9 days (as marked at the axis $\mathrm{x}$ ) of conditioning with $50 \mathrm{ng} / \mathrm{ml} \mathrm{NGF}$. Differentiated cell was defined as a cell with neurite length greater that the diameter of a cell body. Values are mean \pm SEM from three independent experiments each consisting of 12 replicates ( 3 dishes $/ 4$ fields). B. Average neurite length measured from differentiated cells after 2, 5, 7 and 9 days (as marked at the axis $\mathrm{x}$ ) of conditioning with 50 $\mathrm{ng} / \mathrm{ml} \mathrm{NGF}$. Values are mean \pm SEM from three independent experiments each consisting of 12 replicates ( 3 dishes/ 4 fields). Control, cells cultured with NGF only; grey, cells cultured with NGF and DMSO; black, cells cultured with NGF and $1 \mu \mathrm{M}$ isradipine. course followed the expression of functional calcium channel proteins as is documented by sigmoidal increase of a total calcium current amplitude (Figure 1B).

It is known that differentiated PC12 cells express predominantly L-type and N-type calcium channels (Usowicz et al. 1990; Cavalie et al. 1994; Liu et al. 1996; Colston et al. 1998). To evaluate the portion of the total calcium current carried through LTCCs we blocked these channels by $10 \mu \mathrm{M}$ nimodipine (Figure 1C). In these experiments current was activated by $50 \mathrm{~ms}$ long depolarizing pulses from a holding potential of $-80 \mathrm{mV}$ to a membrane potential corresponding to the peak of a current-voltage relationship of each investigated cell $(+10$ or $+20 \mathrm{mV})$. Holding potential $\left(\mathrm{V}_{\mathrm{H}}\right)$ of $-80 \mathrm{mV}$ was chosen to minimize current run-down. Inhibition of L-type calcium current by dihydropyridine channel blockers is known to be voltage-dependent and is by approximately one decimal orders less effective at a $\mathrm{V}_{\mathrm{H}}$ $-80 \mathrm{mV}$ compare to a $\mathrm{V}_{\mathrm{H}}-40 \mathrm{mV}$ (Lacinova 2005). Nevertheless, $10 \mu \mathrm{M}$ nimodipine is sufficiently high concentration to achieve a complete block of L-type calcium current even at a $\mathrm{V}_{\mathrm{H}}-80 \mathrm{mV}$ (Lacinova et al. 2000). Therefore a portion of the total calcium current blocked by nimodipine represents the L-type calcium current. Amplitude of the nimodipineblocked current, i.e., an L-type calcium current expressed in $\%$ of total calcium current amplitude is shown in the Figure 1C. The synthesis and membrane targeting of functional L-type calcium channel proteins increased sigmoidaly with a similar time course as the concentration of the CACNA1C mRNA and the total calcium current amplitude (compare Figure $1 \mathrm{~A}, \mathrm{~B}$ and $\mathrm{C}$ ).

LTCCs can be an entry pathway for sustained calcium influx at resting membrane potentials between $-45 \mathrm{mV}$ and $-25 \mathrm{mV}\left(\mathrm{Ca}_{\mathrm{V}} 1.2 \mathrm{~b}\right.$; Fleischmann et al. 1994) or between $-40 \mathrm{mV}$ and $0 \mathrm{mV}\left(\mathrm{Ca}_{\mathrm{V}} 1.2 \mathrm{a}\right.$; Hirano et al. 1992). To test whether such windows current may be active in PC12 cells during our cell culture conditions we measured resting membrane potential of these cells using bath solution mimicking ionic composition of culture media. In these experiments pipette solution contained (in mM): MgATP 3, HEPES 10, EGTA 10, KCl 130, NaGTP 0.4, pH 7.4 (CsOH). Bath solution contained (in $\mathrm{mM}$ ): $\mathrm{NaCl} 109.51, \mathrm{KCl} 5.36, \mathrm{HEPES} 10$, $\mathrm{CaCl}_{2}$ 1.36, $\mathrm{MgSO}_{4}$ 0.81, $\mathrm{NaHCO}_{3} 44.04, \mathrm{NaH}_{2} \mathrm{PO}_{4}$ 0.91, D-glucose 24.98, pH 7.4 (NaOH). NGF-activated neurodifferentiation was accompanied by statistically significant hyperpolarization of resting membrane potential (day 2: $-24.2 \pm 2.1 \mathrm{mV} ; n=9$; day $5:-28.1 \pm 2.0 \mathrm{mV} ; n=8$; day 7 : $-33.4 \pm 3.4 \mathrm{mV} ; n=10$; day 9: $-35.3 \pm 4.7 \mathrm{mV} ; n=10$; all values are means \pm SEM). These membrane potentials may allow window calcium current through LTCCs.

To test if the potential spontaneous activity of LTCCs does support NGF-activated differentiation we cultured the PC12 cells in a presence of dihydropyridine channel blocker isradipine in a concentration of $1 \mu \mathrm{M}$. To see if such concentration 
is sufficient for complete block of L-type calcium current in PC12 cells we compared the inhibition of total calcium current after 9 days of NGF treatment by $10 \mu \mathrm{M}$ nimodipine and by $1 \mu \mathrm{M}$ isradipine (Figure 1D). Both dihydropyridines were equally effective. Stock solution of isradipine was prepared in DMSO in $50 \mathrm{mM}$ concentration and was dissolved to final concentration in a culture medium prior to each medium exchange. To exclude possible artifact caused by DMSO we cultured in parallel PC12 cells in presence of corresponding concentration of the DMSO only.

Neurite outgrowth was evaluated using Photoshop CS2 9.0. Figure 3 shows results of this analysis. Cell with at least one neurite longer than the cell body diameter was considered to be differentiated. To correct for variation of an initial number of cells in each field the number of differentiated cells was expressed in percentage of all cells in the investigated field. Neither DMSO nor isradipine affected proportion of differentiated cells (Figure 3A). Average neurite length was evaluated by measuring total length of all neurites in a field and dividing this number by a number of differentiated cells in that field. Average neurite length was not altered by isradipine or by vehicle alone (Figure 3B) as well.

Our finding extends current knowledge about the role and source of intracellular calcium ions in neurodifferentiation of PC12 cells. Lu and coauthors (Lu et al. 2009) reported that an activity of voltage-gated calcium channels is necessary for Numb-mediated neurite outgrowth in PC12 cells. Zhaleh and coauthors (Zhaleh et al. 2011) showed that calcium entry from the extracellular space through an unidentified pathway supports neurodifferentiation of PC12 cells activated by a protein kinase $\mathrm{C}$ inhibitor staurosporine. From our results we can conclude that while NGF-driven differentiation is accompanied by enhanced expression of functional L-type calcium channels, activity of these channels is not required for neurite outgrowth. In our model NGF activated neurite outgrowth by a pathway which does not include Numb protein. We cannot exclude that L-type calcium channels may contribute to staurosporine-induced neurite outgrowth, because we did not control the activity of protein kinases in our model.

Acknowledgements. This work was supported by the Slovak Research and Development Agency under the contract No. APVV-0212-10 and VVCE-0064-07. Authors wish to thank Dana Jurkovicova for a helpful discussion and Emilia Kocurova for an excellent technical assistance. Authors declare no conflict of interest and no financial interest in the publication of this manuscript.

\section{References}

Cavalie A., Berninger B., Haas C. A., Garcia D. E., Lindholm D. Lux H. D. (1994): Constitutive upregulation of calcium chan- nel currents in rat phaeochromocytoma cells: role of c-fos and c-jun. J. Physiol. 479, 11-27

Colston J. T., Valdes J. J., Chambers J. P. (1998): $\mathrm{Ca}^{2+}$ channel a 1-subunit transcripts are differentially expressed in rat pheochromocytoma (PC12) cells following nerve growth factor treatment. Int. J. Dev. Neurosci. 16, 379-389 http://dx.doi.org/10.1016/S0736-5748(98)00036-7

Eva R., Bouyoucef-Cherchalli D., Patel K., Cullen P. J., Banting G. (2012): IP3 3-kinase opposes NGF driven neurite outgrowth. PLoS One 7, e32386

http://dx.doi.org/10.1371/journal.pone.0032386

Fleischmann B. K., Murray R. K., Kotlikoff M. I. (1994): Voltage window for sustained elevation of cytosolic calcium in smooth muscle cells. Proc. Natl. Acad. Sci. U.S.A. 91, 11914-11918 http://dx.doi.org/10.1073/pnas.91.25.11914

Greene L. A., Tischler A. S. (1976): Establishment of a noradrenergic clonal line of rat adrenal pheochromocytoma cells which respond to nerve growth factor. Proc. Natl. Acad. Sci. U.S.A. 73, 2424-2428 http://dx.doi.org/10.1073/pnas.73.7.2424

Hansen T. O., Rehfeld J. F., Nielsen F. C. (2003): KCl potentiates forskolin-induced PC12 cell neurite outgrowth via protein kinase A and extracellular signal-regulated kinase signaling pathways. Neurosci Lett. 347, 57-61 http://dx.doi.org/10.1016/S0304-3940(03)00581-0

Heo D. K., Chung W. Y., Park H. W., Yuan J. P., Lee M. G., Kim J. Y. (2012): Opposite regulatory effects of TRPC1 and TRPC5 on neurite outgrowth in PC12 cells. Cell Signal. 24, 899-906 http://dx.doi.org/10.1016/j.cellsig.2011.12.011

Hirano Y., Moscucci A., January C. T. (1992): Direct measurement of L-type $\mathrm{Ca}^{2+}$ window current in heart cells. Circ. Res. 70, 445-455 http://dx.doi.org/10.1161/01.RES.70.3.445

Ishima T., Hashimoto K. (2012): Potentiation of nerve growth factor-induced neurite outgrowth in PC12 cells by ifenprodil: the role of sigma-1 and IP3 receptors. PLoS One 7, e37989 http://dx.doi.org/10.1371/journal.pone.0037989

Jurkovicova D., Kopacek J., Stefanik P., Kubovcakova L., Zahradnikova A., Jr., Zahradnikova A., Pastorekova S., Krizanova O. (2007): Hypoxia modulates gene expression of IP3 receptors in rodent cerebellum. Pflügers Arch. 454, 415-425 http://dx.doi.org/10.1007/s00424-007-0214-6

Kolkova K., Novitskaya V., Pedersen N., Berezin V., Bock E. (2000): Neural cell adhesion molecule-stimulated neurite outgrowth depends on activation of protein kinase $\mathrm{C}$ and the Ras-mitogen-activated protein kinase pathway. J. Neurosci. 20, 2238-2246

Kumar S., Chakraborty S., Barbosa C., Brustovetsky T., Brustovetsky N., Obukhov A. G. (2012): Mechanisms controlling neurite outgrowth in a pheochromocytoma cell line: the role of TRPC channels. J. Cell. Physiol. 227, 1408-1419 http://dx.doi.org/10.1002/jcp.22855

Lacinova L., Klugbauer N., Hofmann F. (2000): State- and isoform-dependent interaction of isradipine with the a1C L-type calcium channel. Pflügers Arch. 440, 50-60 http://dx.doi.org/10.1007/s004249900244

Lacinova L. (2005): Voltage-dependent calcium channels. Gen. Physiol. Biophys. 24 (Suppl. 1), 1-78 
Liu H., Felix R., Gurnett C. A., De Waard M., Witcher D. R., Campbell K. P. (1996): Expression and subunit interaction of voltage-dependent $\mathrm{Ca}^{2+}$ channels in PC12 cells. J. Neurosci. 16, 7557-7565

Lu C. B., Fu W., Xu X., Mattson M. P. (2009): Numb-mediated neurite outgrowth is isoform-dependent, and requires activation of voltage-dependent calcium channels. Neuroscience 161, 403-412 http://dx.doi.org/10.1016/j.neuroscience.2009.03.063

Meng F., To W. K., Gu Y. (2008): Role of TRP channels and NCX in mediating hypoxia-induced $[\mathrm{Ca}(2+)](\mathrm{i})$ elevation in $\mathrm{PC} 12$ cells. Respir. Physiol. Neurobiol. 164, 386-393 http://dx.doi.org/10.1016/j.resp.2008.09.002

Oda T., Kume T., Izumi Y., Ishihara K., Sugmimoto H., Akaike A. (2011): $\mathrm{Na}^{+} / \mathrm{Ca}^{2+}$ exchanger inhibitors inhibit neurite outgrowth in PC12 cells. J. Pharmacol. Sci. 116, 128-131 http://dx.doi.org/10.1254/jphs.11011SC

Pollock J. D., Krempin M., Rudy B. (1990): Differential effects of NGF, FGF, EGF, cAMP, and dexamethasone on neurite outgrowth and sodium channel expression in PC12 cells. J. Neurosci. 10, 2626-2637

Puntambekar P., Mukherjea D., Jajoo S., Ramkumar V. (2005): Essential role of Rac1/NADPH oxidase in nerve growth factor induction of TRPV1 expression. J. Neurochem. 95, 1689-1703 http://dx.doi.org/10.1111/j.1471-4159.2005.03518.x

Sirabella R., Secondo A., Pannaccione A., Molinaro P., Formisano L., Guida N., Di Renzo G., Annunziato L., Cataldi M. (2012): ERK1/2, p38, and JNK regulate the expression and the activity of the three isoforms of the $\mathrm{Na}(+) / \mathrm{Ca}(2+)$ exchanger, NCX1, NCX2, and NCX3, in neuronal PC12 cells. J. Neurochem. 122, 911-922 http://dx.doi.org/10.1111/j.1471-4159.2012.07838.x

Usowicz M. M., Porzig H., Becker C., Reuter H. (1990): Differential expression by nerve growth factor of two types of $\mathrm{Ca}^{2+}$ channels in rat phaeochromocytoma cell lines. J. Physiol. 426, 95-116

Vaudry D., Stork P. J., Lazarovici P., Eiden L. E. (2002): Signaling pathways for PC12 cell differentiation: making the right connections. Science 296, 1648-1649 http://dx.doi.org/10.1126/science.1071552

Zhaleh H., Azadbakht M., Pour A. B. (2011): Effects of extracellular calcium concentration on neurite outgrowth in PC12 cells by staurosporine. Neurosci. Lett. 498, 1-5

http://dx.doi.org/10.1016/j.neulet.2011.04.020

Received: October 10, 2012

Final version accepted: November 8, 2012 